\title{
THE CONOPIDAE OF THE WEST INDIES AND BERMUDA (DIPTERA).
}

\author{
By C. T. PARSONS
}

Biological Laboratories, Harvard University

No Conopidæ have been recorded from Bermuda and only three species from the West Indies. Of these three species, one is almost certainly incorrectly identified, and the second has always been placed as a synonym of the third. In this paper the synonymized name is resurrected and six species are described as new. Since the members of the Conopidæ are usually widely distributed, comparisons were made with the entire New World fauna.

The origins of the West Indian Conopidæ are obscured by the scarcity of data, since no representatives are yet known from Jamaica or the Lesser Antilles. Trinidad, from which Kröber has recorded Physocephala testacea v.d. Wulp (Argentina), is usually regarded as part of South America. The Conops herein described from Bermuda is so distinctive that nothing can be said concerning its relationships. No true Conops are yet known from the West Indies, but the Antillean Physoconops and Zodion show more or less definite affinities with Middle or South American forms. The unique Physocephala seems to be closely allied to a Costa Rican variety of a widely distributed South American species. The single Occemyia represents the first southern extension of the genus from the Nearctic region. The predominantly South American aspect of the West Indian Conopidæ is consistent with the fact that the Nearctic forms strongly indicate a Neotropical origin.

\section{Conops Linnaeus}

Linnaeus, 1758, Syst. Nat., p. 604, no. 226.

True Conops (s. str.) occurs generally throughout the 
New World, but so far has not been found in the West Indies.

Conops bermudensis new species (Fig. 3)

Female: length $7 \mathrm{~mm}$. Easily recognized by its dark color, entirely yellowish wings, and black spot in front of each eye. Front and vertex dark reddish brown; cheeks somewhat paler; face testaceous; a round, black, velvety spot in front of and contiguous with each eye at a level with the base of the antennæ. Fine silver pollen on face and cheeks and extending up to the black spot. Basal segments of antennæ dark brown, more than three times as long as wide; other segments missing. Proboscis dark brown, darker towards the apex, twice the length of the head. Thorax dark brown, obscurely covered with very fine silver pollen; mesonotum (except the humeri) black; scutellum dark brown; metanotum black. Legs dark brown; tibiæ becoming darker towards their apices; tarsi dark piceous; pulvilli and claws pale testaceous; tips of claws black. Coxæ covered with very fine silver pollen. Abdomen dark brown, covered with very fine silver pollen, particularly on the sixth and seventh segments. Ventral plate rather long, very convex and broad. Wings entirely uniformly pale yellowish brown.

Holotype ( $q$ ) : Bermuda (Owen Bryant) ; in the Museum of Comparative Zoology.

The specimen is in rather poor condition, but is worth describing because it represents the first Conopid to be found in Bermuda. Most of the Nearctics species heretofore described under Conops really belong in Physoconops. But bermudensis is a true Conops and so distinctive that it cannot be confused with any other species.

\section{Physoconops Szilady}

Szilady, 1926, Annal. Mus. Nat. Hungar., 24 : 588.

Physoconops cubanus new species (Figs. 6, 7)

Female: length without antennæ 10.5-11 mm. Front dark testaceous, vertex and median line, extending to the antennæ, piceous. Face and checks testaceous; anterior and posterior orbital margins covered with golden pollen. Proboscis 
dark piceous, apex black; less than twice the length of the head. Antennæ as figured, dark piceous, proximal segment paler. Thorax black; humeri brown with the inner side covered with golden pollen; also golden pollen on the mesonotum surrounding the humeri and on the mesopleuræ and sternopleuræ. Scutellum either black or with obscure golden pollen. Metanotum black, anterior half covered with golden pollen; most of metapleuræ covered with golden pollen. Halteres testaceous. Legs testaceous, tarsi black except at their proximal ends. Anterior surface of anterior coxæ and outer surfaces of fore and middle tibiæ covered with golden pollen. Pulvilli and claws testaceous, tips of claws black. Abdomen as figured; segments one and two black, with golden pollen on the posterior margins; the third segment with an obscure proximal yellow band; segments apical to two are dark rufous. Ventral plates of medium length and definitely narrowed at the tip, black on the posterior side. Wings hyaline with reddish brown band becoming fuscous at apical half. The dark band is paler in the costal cell; extends posteriorly to the first basal cell, to the vena spuria, and to a narrow hyaline margin in the distal half of the first posterior cell, but filling out the cell at its apex.

Male: length without antennæ $12 \mathrm{~mm}$. Similar to the female but the golden pollen almost absent in the only specimen. The yellow band at the base of the third abdominal segment broader and more distinct than in the female.

Holotype ( q ) : Sept. 2, 1930, Guabairo about 4 miles north of Soledad, near Cienfuegos, Cuba (Richard Dow); allotype and paratype ( $q$ ) with same data as holotype; in the $\mathrm{Mu}-$ seum of Comparative Zoology.

In Kröber's key (1939, Ann. Mag. N.H., 4: 467) cubanus runs to fronto Will. but differs in having a relatively longer third antennal segment, and differently colored thorax, front, occiput, and abdomen. In Van Duzee's key (1927, Proc. Calif. Ac. Sci., 16:578) cubanus runs to gracilis Will., but gracilis is a true Conops.

Physoconops bahamensis new species (Figs. 8, 9)

Female: length without antennæ $13 \mathrm{~mm}$. Vertex piceous with a black center; front testaceous becoming piceous or 
black at its upper margin. Face and cheeks pale testaceous; the facial depression and orbital margins with golden pollen. Antennæ as figured, piceous, the second segment thickly setaceous. Proboscis rufo-testaceous, tip piceous, less than twice as long as the head. Thorax black, a silver pollen spot on the inner side of each humerus and extending to the base of each wing. Anterior half of the scutellum, metanotum, and metapleuræ covered with silver pollen. A silver pollinate band on mesopleuræ and sternopleuræ. Anterior surface of prothoracic coxæ covered with golden pollen, the other coxæ with silver pollen. Femora bright rufo-testaceous; tibiæ pale testaceous, the proximal halves very pale; tersi black, paler at their proximal ends; pulvilli and claws pale yellow, tips of claws black. Halteres pale yellow. Abdomen as figured; first segment black, rest of the abdomen black. The posterior margins of the first, second, and third segments with silver pollen. The dorsal surface of the sixth segment covered with silver pollen. Fifth segment strongly constricted; the ventral plate very long. Wings with yellowish brown band in veins 1-5, except that the apical half of the second posterior cell is hyaline, and a narrow band along the posterior margin of the first posterior cell (except at the extremity) is hyaline. The brown band becomes fuscous at the apical third of the wing.

Holotype ( o ) : February 8, 1934, Eleuthera Island, Bahama Islands (Utowana Expedition) in the Museum of Comparative Zoology.

It is difficult to see what are the relationships of this species. In the key just published by Kröber (1939, Ann. Mag. N.H., 4: 466-467) bahamensis might run to rufipennis Macq. or discalis Will., depending on how one interprets the color of the wings. Macquart's species, however, has a differently colored head, scutellum, tarsi, and abdomen. Williston's discalis has a much shorter third antennal joint, black front, and other differences. Of the North American species, bulbirostris Loew is perhaps closest.

Physoconops ramondi (Bigot) (Figs. 1, 2)

Conops ramondi Bigot, 1857, in Ramond de la Sagra's Cuba, vol. 7 , p. 808 ; pl. 20 , fig. 6 . 
Conops pictus Fab. of authors, in error.

Female: length without antennæ $21 \mathrm{~mm}$. Easily distinguished by its very large size and reddish brown color. Front, face, cheeks reddish brown. There is yellow pollen in the facial depression and extending along the facial and posterior orbits up to a little above the level of the base of the antennæ. In certain angles of light the pollen shows as a golden sheen. Proboscis reddish brown, evidently less than twice the length of the head (in the single female the apex is broken off). Antennæ as figured; reddish brown, style paler, second segment thickly covered with black setæ. Thorax reddish brown, a pair of obscure longitudinal piceous lines on anterior part of mesonotum and one near each margin of the mesonotum. Humeri without pollen, but an irregular golden pollen spot on the inside of each humerus and posterior from the humeri to the wing bases. An oblique golden pollen band on the mesopleuræ and sternopleuræ. Golden pollen hardly discernible on the reddish brown scutellum but forming a yellow band across the anterior half of the metanotum. Halteres dull yellow. Legs pale reddish brown, coxæ covered with a silvery yellow sheen; distal halves of the tibiæ covered with a yellow sheen, especially on the outer side; tarsi black, pale at each end; tips of claws black. Abdomen as figured; reddish brown; the posterior margins of the first and second segments with golden pollen, particularly on the sides; two obscure piceous stripes on the second segment; ventral plate very long, black on the posterior side. Wings hyaline, with a reddish brown streak from the first to the fourth veins, tending to be fuscous distally; posterior part of first posterior cell and most of the second posterior cell hyaline.

Male: length without antennæ $20.5 \mathrm{~mm}$. Similar to the female but the style much longer and more attenuate; proboscis darker, with a black tip ; first to third abdominal segments much thinner, and more pollen on the scutellum.

Described from a pair collected by C. T. Ramsden in 1910 ( 8 May 31, o June 21) on the Rio Seco, Quantanamo, Cuba in the C. W. Johnson collection of the Museum of Comparative Zoology.

Osten Sacken, in his catalogue (1878, p. 255), quotes Loew as stating in litt. that ramondi is the same as pictus Fab., and 
as a result of Loew's dictum ramondi has remained a synonym to this day. Since ramondi is twice the size of pictus and accurately figured in color by Bigot, it is inconceivable how Loew made such a statement. The specimens described above, however, were correctly named by Johnson.

\section{Physoconops pictus (Fabricius)}

Conops picta Fab., 1775, Syst. Ent., 4:391 (West Indies). Conops ramondi Bigot of authors, in error.

This species appears to be restricted to the West Indies. Macquart recorded it from the United States ("Carolina") and Weidemann from South America, but these references are almost certainly to other species. In the Museum of Comparative Zoology there are specimens from Cuba, Haiti, and Puerto Rico. The American Museum of Natural History also has specimens from Cuba and Puerto Rico. Kröber, 1939 , records pictus from "S. Domingo".

Another species, for which good structural differences cannot at present be found, is represented in the Museum of Comparative Zoology by two specimens labelled "Cuba", one from "Havana, Cuba, Baker", and one from Buenos Aires, Trinidad Mts., Cuba, June 17-23, C. Parsons. This species differs from pictus in having a dark rufous abdomen, black scutellum; etc. It is perhaps intermediate between pictus and cubanus.

\section{Physocephala Schiner}

Physocephala Schiner, 1861, Wien. Ent. Monatssch., 5: 137.

Physocephala venusta new species (Figs. 12, 13)

Female: length without antennæ $9.5 \mathrm{~mm}$. Face and front yellow except for a sinuous rufo-piceous transverse band contiguous with the vertex and extending medially down to the antennæ but not divaricating at the antennæ. Antennæ as figured, rufo-testaceous, the third segment and style somewhat paler, the distal end of the first and dorsal and lateral sides of the second segment covered with black setæ. Cheeks pale piceous with an obscure testaceous spot. Silvery white pollen extends along the eyes half way up the front. Proboscis dark piceous, about twice as long as the head. Mesonotum 
black, surrounded by a margin of gold pollen, except at the median third on the anterior margin. Sides of the thorax dark rufo-piceous with an irregular oblique band of golden pollen. Scutellum black; metanotum black with a large spot of golden pollen on each side. The halteres pale yellow. Coxæ dark rufo-piceous covered with coarse silvery pollen; trochanters and bases of the femurs pale testaceous; femora dark piceous except about the distal fourths, which are pale testaceous; tibiæ and tarsi pale testaceous, tips of claws black. Abdomen as figured, rufo-piceous tending to be darker dorsally and towards the base of each segment. Posterior margins of the segments with obscure golden pollen; except for a broad patch on each side of the distal end of the first segment and generally on the dorsal surface of the sixth segment. The ventral plate rufo-testaceous, black from behind, when seen from below angulate, forming an angle of $120^{\circ}$. Wings subhyaline, costal and subcostal cell testaceous; the usual brown stripe extends from the first vein to fifth, slightly beyond the apex of the second posterior cell, and does not fill up completely the first posterior cell.

Holotype ( 9 ) : Nov. 16-17, 1934, Mannville, Haiti (P. J. Darlington, Jr.) in the Museum of Comparative Zoology.

Of the Nearctic species venusta is clearly nearest to sagittaria Say. But sagittaria is larger, has a longer style, longer second antennal joint, the median black frontal line divaricating at the antennæ, larger and more rounded ventral plate, and color differences.

A Neotropical species which appears to be very closely related to venusta is bimaculata Kröber, described, from Argentina, Ecuador, and Colombia. According to Kröber's deseription (1915, Archiv. f. Naturgesch. Abt. A, H. 4, p. 140) bimaculata is much larger, has a shorter second antennal joint, scutellum reddish brown instead of black, abdomen black with much more yellow, and the ventral plate larger and rounded, not angulate. Kröber (Konowia, 5:130) gives a supplementary description and figures of bimaculata from Costa Rica. The figures show that venusta is near but distinct from bimaculata.

Zodion Latreille

Zodion Latreille, 1796, Préc. des caract. gen. d. Ins., p. 162. 


\section{Zodion canescens new species (Figs. 4, 5)}

Female: length $5 \mathrm{~mm}$. Face yellow with the depressed central portion piceous; a few fine pale hairs on the cheeks, longer and darker hairs on front and vertex; front piceous, becoming darker towards the vertex; shining space around the ocelli broadly angular anteriorly. Face and cheeks covered with pale yellow pollen. Antennæ as figured, first and second segments piceous, the third rufo-testaceous. Proboscis twice as long as the head. Thorax piceous, covered with grey pollen except for three broad dorsal longitudinal piceous lines. The legs piceous but the femora, except at their distal ends, and tibiæ more or less feebly covered with grey pollen. Halteres yellow; calypteres white. Wings subhyaline, veins piceous, first posterior cell broadly closed. The abdomen as figured, segments one to four and all but the posterior margin of the fifth black, covered with grey pollen, except along two broad dorsal bands. The apical segments and ventral plate are rufo-testaceous.

Holotype ( ) : April 12, 1926, Soledad, near Cienfuegos, Cuba in the American Museum of Natural History.

Among the North American species canescens is closely related to fulvifrons Say. But fulvifrons has a broad low ventral plate, longer proboscis, paler front, etc. Among the Neotropical species canescens is apparently very near to americanum Wied. According to Kröber, who examined the male type from Uruguay, americanum differs in having a pale front, proboscis more than twice the length of the head, two narrow black lines on the thorax, differently marked and colored abdominal segments. Kröber says that a female, without a head, next to the type is identical with nanellum Loew. If this is so, then the anal segment and ventral plate of americanum is very different from canescens.

\section{Zodion species $v i x$ americanum Wied.}

In the U. S. Nat. Museum is a Zodion from San Diego de Los Banos, Pinar del Rio, Cuba which is labelled americanum Wied. Unfortunately it is a male, but it seems to be much closer to canescens than to americanum. Roeder (1885, Stett. Ent. Zeit., $46: 343$ ) records americanum from Puerto Rico, but very likely it is not true americanum. 


\section{Occemyia Robineau-Desvoidy}

Thecophora Rondani, 1845, Nuovi Annali d. Sci. Nat., $3: 15$ Occemyia Robineau-Desvoidy, 1853, Dipt. Eur. Paris, Myop., p. 50

Oncomyia Loew, 1866, Berlin ent. Zeit., 10: 41 (emend. of Occemyia)

Thecomyia Brues and Melander, 1932, Bull. M.C.Z., 73: 306 (lapsus calami).

All writers except Coquillett have overlooked the 1845 description of Thecophora. They cite the 1857 description, but even so Rondani's name is preoccupied by Charpentier's use of it for a subgenus of Odonata (1840). Since Charpentier's name was Thecaphora a strict application of the rules would necessitate the use of Rondani's Thecophora. It may be argued, however, that Rondani's name is invalid since he did not clearly indicate a species with the genus. Thecomyia (Tetanoceratidæ) was a slip for Thecophora.

Occemyia haitiensis new species (Figs. 10, 11)

Female: length $4 \mathrm{~mm}$. Shining dark piceous, except the following parts which are more or less pale testaceous; face, cheeks, lower half of antennæ, basal half of inner side of third antennal joint, halteres, calypters, anterior surface of front coxæ, basal half of hind femora, narrow base of four anterior femora, distal tips of femora and bases of tibiæ, extreme tips of tibiæ and basal joints of tarsi. Front between vertex and base of antennæ rufo-testaceous. The shining space around the ocelli extends downward in an acute point. Front, occiput, thorax and abdomen with quite long black hair. Posterior lateral third of second abdominal segment and posterior margin of next two segments with silvery pollen. The hairs at the extremity of the abdomen somewhat pale. Each cheek with a group of about four very short black hairs and along each oral margin a row of black hairs which are about as long as the first antennal segment. Cheeks with silvery white pollen, which extends narrowly to top of eye on the frontal orbit and to the middle of the eye on posterior orbit. Antennæ as figured. Palpi small and piceous; proboscis with apical segment in the female a 
little shorter than the first, unknown in the male. Ventral plate of female narrow and rather long, shining piceous. Veins of wings uniformly piceous but becoming paler at the base.

Holotype ( o ) : Port-au-Prince, Haiti (William Mann) in the Museum of Comparative Zoology.

In Van Duzee's key haitiensis runs to nigra Van Duzee from Oregon. But it differs from nigra in the shape and color of the antennæ, the pale hairs on the abdomen, darker front, the relative lengths of the first and second segments of the proboscis, etc. The new species is perhaps nearest to loraria Loew from eastern United States. But loraria has a shorter ventral plate, paler front, and dark hairs on the cheeks absent or very few and fine.

\section{EXPLANATION OF PLATE IV.}

Figs. 1-13: Antennæ and abdomens of female Conopidæ. All are enlarged the same amount, except $P$. ramond $i$ which is enlarged half as much as the others. 1, 2: Physoconops ramondi; 3: Conops bermudensis; 4, 5: Zodion canescens; 6, 7: Physoconops cubanus; 8, 9: Physoconops bahamensis ; 10, 11: Occemyia haitiensis; 12, 13: Physocephala venusta. 


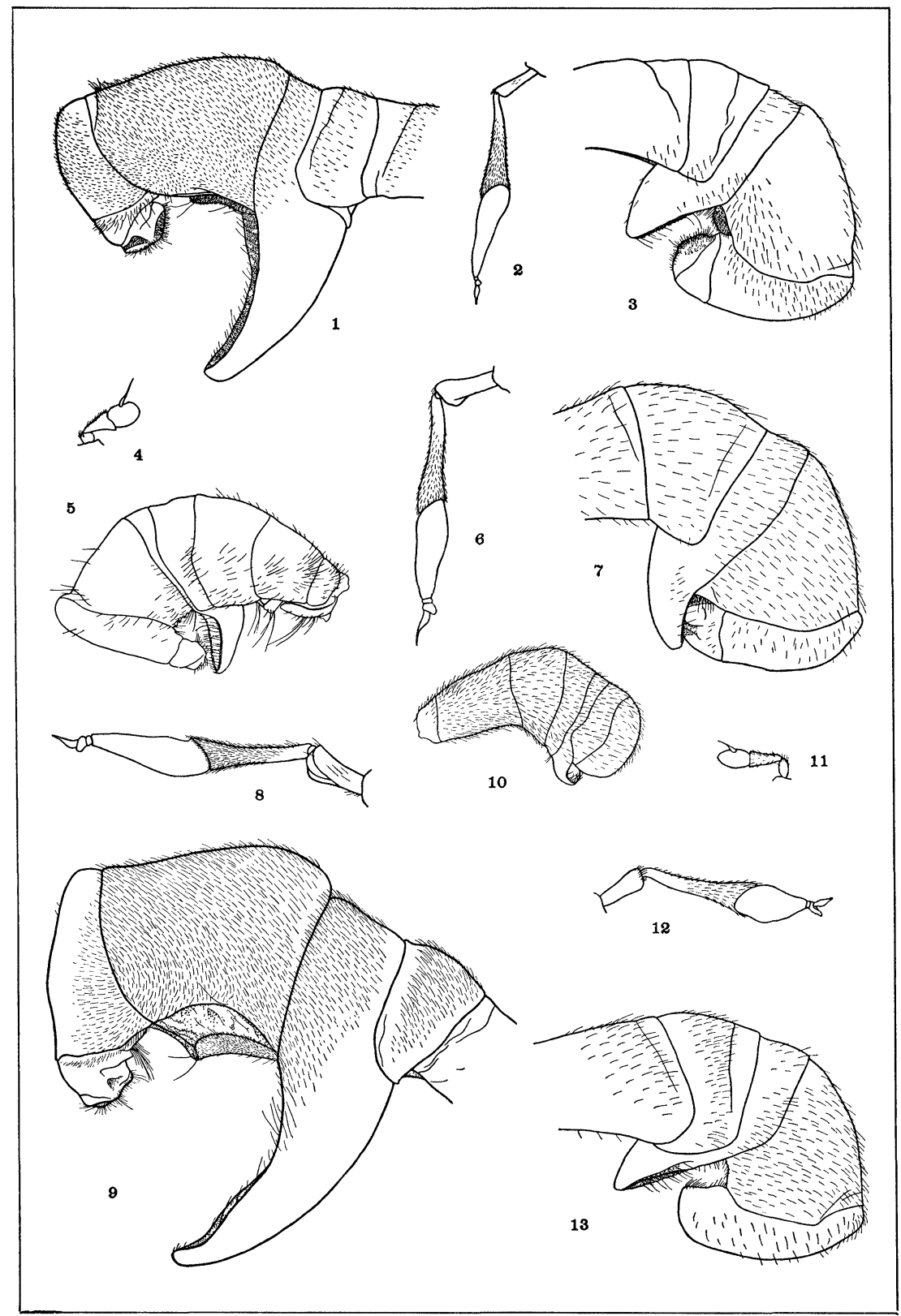

Parsons - Conopidæ 

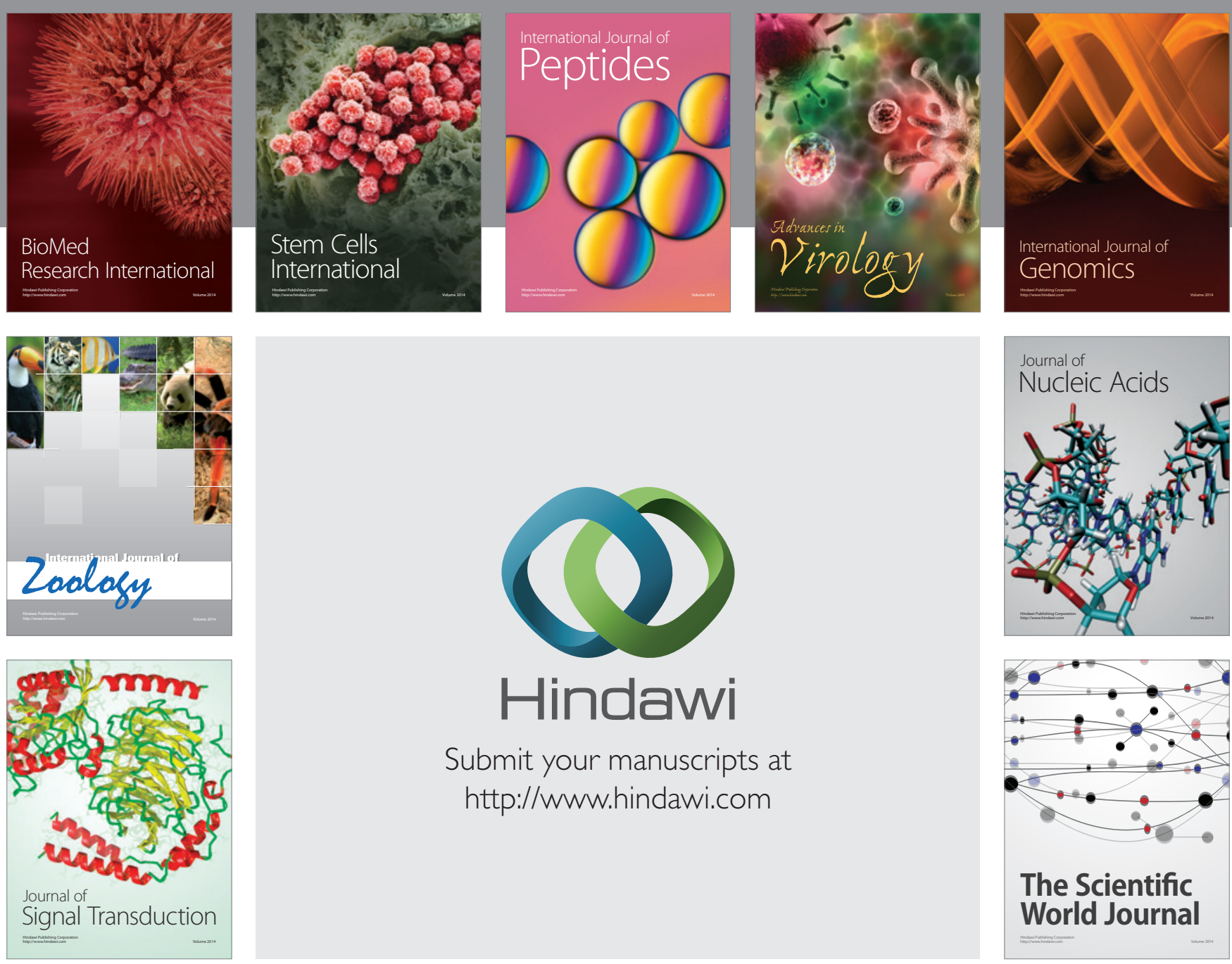

Submit your manuscripts at

http://www.hindawi.com
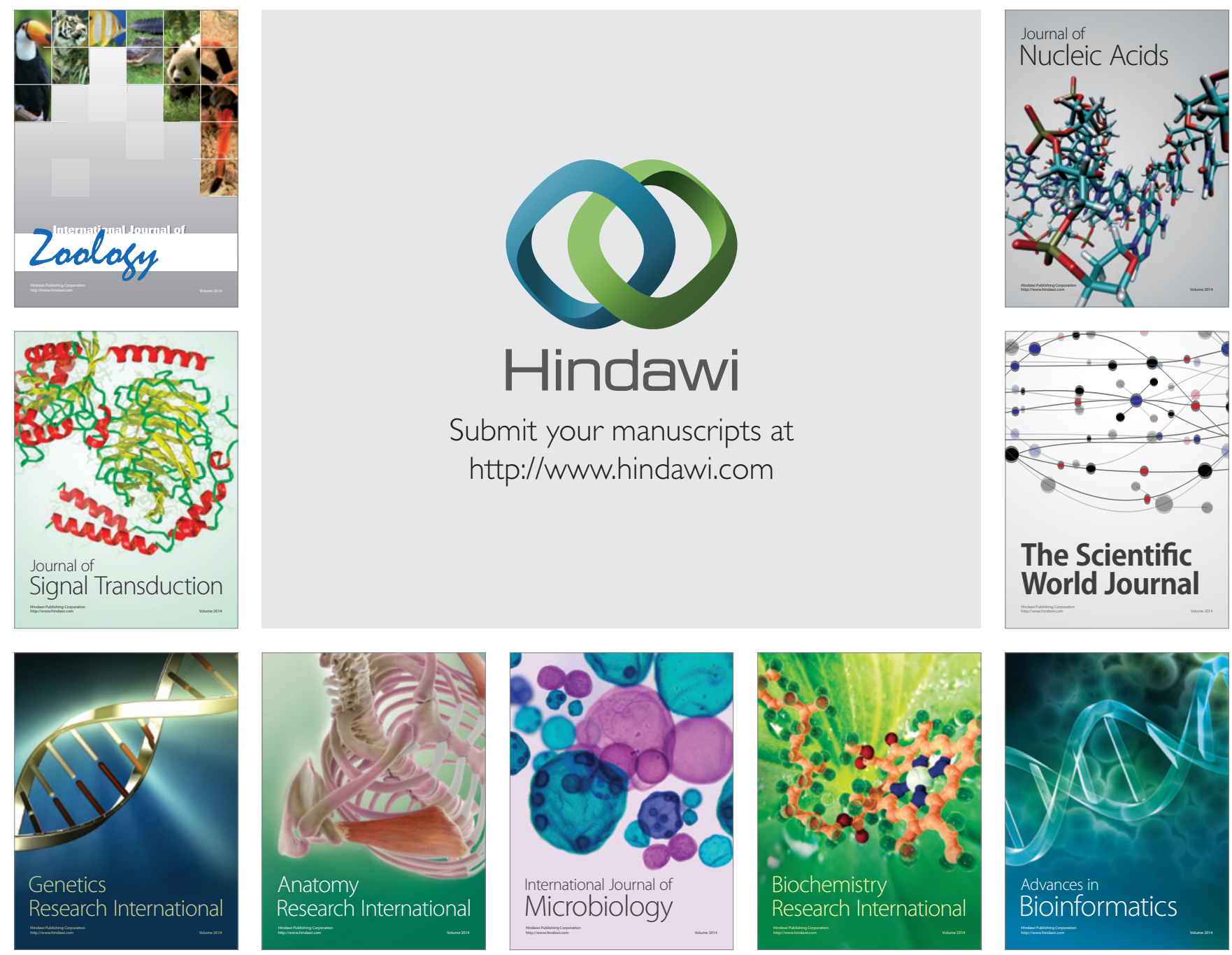

The Scientific World Journal
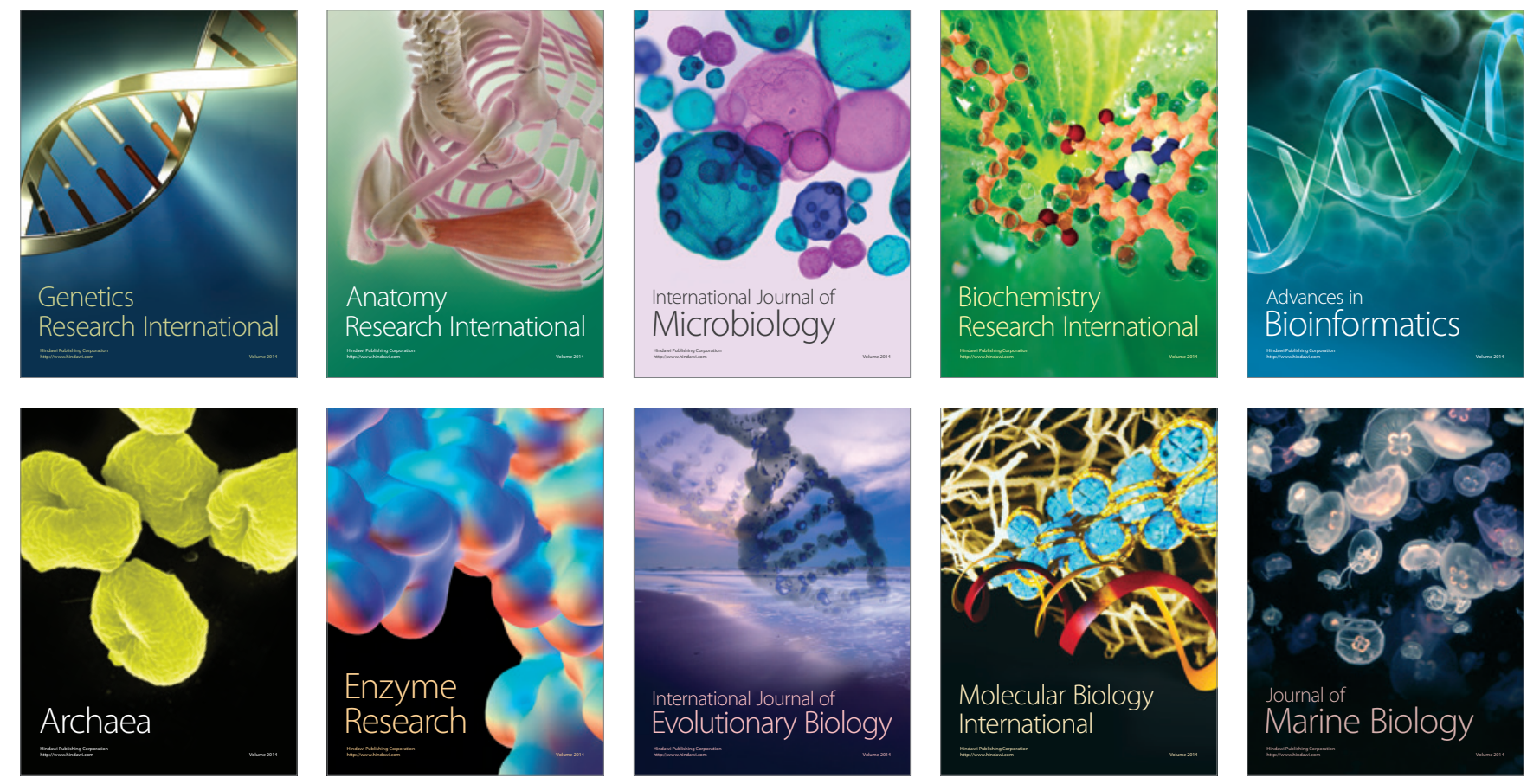